\title{
EXPERIMENTAL STUDIES OF THE
}

\section{PHYS ICS OF LASER FUS ION*}

J. A. Stamper, S. E. Bodner, P. C. Burkhalter, R. Decoste**, G. $\Lambda$. Doschck, U. Fcldman, R. II. Icchmbcrg, E. A. Mclcan, J. M. McMahon, D. J. Nage1, B. H. Ripin, R. R. Whitlock, and

$$
\text { F. C. Young }
$$

Naval Research Laboratory, Washington, D.C.

\section{ABSTRACT}

A discussion is given of selected topics relating to experimental studies of laser-matter interactions under conditions of interest to laser-fusion. The NRL laser system, PHAROS II, designed for such studies, is first described. Some of the more novel diagnostics (probing beam, ion, $x$-ray) are then described. Finally, a discussion is given of two experimental studies which yield information (B-field dependence and inhibition) about thermal transport.

Work supported by ERDA.

**University of Maryland, College Park, Maryland. Partially supported by a Hydro-Quebec Fellowship, Canada. 